\title{
雪室モデルを用いたチーズの雪利用貯蔵の有効性に関する検討
}

\author{
神山 伸 ${ }^{\dagger}$ ，田山 舞，須垴奈美，太田ひかる，金子未来，曾根英行 \\ 新潟県立大学 人間生活学部 健康栄養学科
}

\section{Evaluation of Effectiveness of Snow Utilization for Preservation of Cheese by a Model Experiment}

\author{
Shin KAMIYAMA ${ }^{\dagger}$, Mai TAYAMA, Nami SUZAKI, \\ Hikaru OHTA, Miku KANEKO, Hideyuki SONE \\ Department of Health and Nutrition, Faculty of Human Life Studies, University of Niigata Prefecture, \\ 471 Ebigase, Higashi-ku, Niigata city, Niigata 950-8680, Japan
}

\begin{abstract}
Snow-storage room (namely yukimuro) is a cooling system that has been used to preserve foods under low temperature and high humidity conditions. In the present study, we investigated the effectiveness of snow utilization for the preservation and ripening of cheese by using a snow-storage room model, which was constructed of a low-temperature, high-humidity refrigerator with crushed ice. When a Camembert cheese was stored in a conventional refrigerator for a month, its water content was significantly decreased not only under air-exposed conditions but also sealed in a gas barrier package. In contrast, the water content of the cheese stored in the snow-storage room model was comparable to that of its initial state even under air-exposed conditions. In addition, both the Camembert and Gouda cheeses stored in the snow-storage room model had good color and texture profiles as compared with those stored in conventional refrigerator. The Camembert cheese stored in the snow-storage room model was preferred by sensory test and showed better evaluation scores regarding color, taste and texture than that stored in conventional refrigerator. Further, the Danish blue cheese stored in the snow-storage room model retained significantly high amount of odor components than that stored in conventional refrigerator. These findings indicate that the conditions in snow-storage room are suitable for preservation and low-temperature ripening of cheese.
\end{abstract}

Keywords: Snow-storage room, yukimuro, cheese, preservation, low-temperature ripening

1. 緒

言

冬季の雪を貯蔵庫内の冷房源として用いる雪室は, 年間を通して低温を保つことができるため，北陸地方 や東北地方などの多雪地域を中心に古くより食品の保 存に用いられてきた。雪室などの雪冷熱エネルギー利 用施設は電気冷蔵庫の普及により次第に消失し，平成 元年では豪雪地域に打いてわずか 3 施設に過ぎなかっ たが，近年では，この氷雪冷熱が環境に優しい冷熱エ ネルギーとして見直されつつあり，平成 28 年には 169 施設に増加している $[\mathrm{i}]$. 雪冷熱エネルギー施設は低コ ストの冷蔵システムを構築することが可能であるのみ ならず，にんじん [1]やじゃがいも，きゃべつ [2]のよ

(受付 2018 年 4 月 6 日，受理 2018 年 6 月 12 日)

テ950-8680 新潟市東区海老ヶ瀬 471

$\dagger$ Fax 025-368-8269, e-mail kammy@unii.ac.jp
うな農作物では雪利用による品質向上効果が示されて いることから，その $65 \%$ は農産物・加工品などの貯蔵 に用いられている。近年ではコーヒー [3] や小麦粉 [4], 日本酒 [5] のような加工食品に打いてもその品質保持抢 よび食味の改善効果が報告されて打り，発醅食品や音 肉などの様々な食品について雪室貯蔵の試みがなされ ているが，その有効性が確認されたものは必ずしも多 くはない.

チーズの熟成と保存は温湿度などの保存条件や微生 物などに大きく影響されることから，低温度・高湿度 の条件が理想とされている。雪利用による乳製品の製 造・貯蔵に関しては，ヨーグルトなどの製造や保存に 雪室が用いられた例があるものの，雪利用貯蔵による チーズの保存・熟成に関する科学的な検討はほとんど なされていなかった。チーズは種類により温度や湿度 などの熟成条件が異なるが，一般的に気流のない低温 高湿の環境が好ましく，高温下での熟成は微生物污染 
やオフフレーバーの生成などの好ましくない影響を与 えやすい。ゴーダチーズのような半硬質チーズの熟成 に打いては酪酸菌などによる異常発酵により膨張や品 質低下を招くことがあることから，温度 $10^{\circ} \mathrm{C}$ 程度，湿 度 $80 \%$ 以上で 4 ヶ月程度熟成させるのが一般的である. また，白カビ系の軟質チーズであるカマンベールチー ズに扣いては最適な熟成状態が重要であり，分解と劣 化が極めて早いことから，高温・高湿度でカビを発生 させた後は過熟成を防ぐために低温・高湿度での熟成 が必要となる [6].ここで，空調を用いない自然対流方 式の雪室は低温・高湿度（室温 $0 \sim 5^{\circ} \mathrm{C}$, 湿度 $95 \%$ 以上) で気流のない安定した環境であり，発酵させるには低 温ではあるものの，チーズの保存にとっては好適な条 件と考えられる。そこで本研究では，室内に貯蔵した 水雪を冷房源として用いる水室型の雪室モデルとして, 内部にクラッシュドアイスを設置した 4 面冷却式の低 温高湿庫を用い，これに軟質チーズであるカマンベー ルチーズと半硬質チーズであるゴーダチーズを 1 ケ月 保存した。そして，その品質の状態と官能検査による 評価を温度・湿度に変動のある冷蔵モデルに保存した ものと比較することにより，チーズに打ける雪室利用 の有効性を検討した.さらに, コーヒー [3] や日本酒 [5], そば [7] などでは雪室貯蔵による香気改善効果や香気保 持効果が報告されていることから，匂いの強いチーズ の代表であるブルーチーズについても同様に雪室モデ ルと冷蔵庫に 1 ヶ月保存したものについて，その香気 に及ぼす影響を検討した。

\section{2. 実 験 方 法}

\section{1 試料の貯蔵条件}

水雪型の雪室モデルとして，ホシザキ電機製の恒温 高湿庫 BR-63SB（ブライン循環による 4 面冷却式）を 使用し，庫内の棚の下段に雪水による保湿打よび香気 吸着を目的としたクラッシュドアイスを設置し，上段 に試料を保存した。温度・湿度に変動のある冷蔵モデ ルとして，市販の家庭用冷蔵庫（MR-15R-S，三菱電 機製）を使用した。保存期間中は，Thermo Recorder おんどとり TR-72wf-H（T\&D Corporation）を用いて， 保存中の庫内の温度と湿度の変化を記録した。それぞ れの庫内の温度と湿度は, 試料を設置した部分にセン サーを配置し測定した。

試料は，軟質チーズとして国産カマンベールチーズ (雪印北海道 100 カマンベールチーズ，雪印メグミルク 株式会社)，および半硬質チーズとしてオランダ産ゴー ダチーズ（セミハードタイプ，株式会社エヌ・シー・ エル，カット）の 2 種類を用い，これらの試料 $100 \mathrm{~g}$ 程度（カマンベールチーズ：100 g ホール，直径 $8 \mathrm{~cm}$ ×高さ $2.5 \mathrm{~cm}$ の円盤状 ; ゴーダチーズ : $100 \mathrm{~g}$ カット,
1 辺 $4.5 \mathrm{~cm}$ 程度の立方体）を上記の冷蔵庫あるいは雪 室モデルで 1 ヶ月間保存した。包材としては，ガスバ リア性のラミネート袋（チャック付 CP 平袋 $140 \times$ $230 \mathrm{~mm}$ ，清和株式会社）を用い，脱気操作をしない状 態でヒートシーラーによる簡易密封を行った。貯蔵終

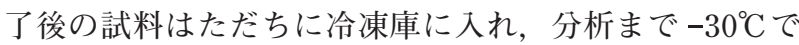
保存した。水分量の変化に関する検討では，カマンベー ルチーズを 8 等分（15 $\mathrm{g}$ 程度）にカットしたものを市 販プラスチックカップ $(200 \mathrm{~mL}$ 容量, ポリプロピレン 製）内に入れ，No.2 濾紙で蓋をしたものを同様にして 冷蔵庫あるいは雪室モデルに 1 ケ月間保存した。香気 分析に関する試料としては，デンマーク産ブルーチー ズ（キャステロブルー $100 \mathrm{~g}$ ）を用いた．包材としては， ガス抜きバルブを付けたラミネート袋（ゴリオバルブ 付チャック付 $\mathrm{CP}$ 平袋，清和株式会社）を用い，上記と 同様にして 1 ヶ月間保存した.

\section{2 水分の測定}

常圧加熱乾燥法により測定した。アルミ皿に細断し た試料 $0.5 \mathrm{~g}$ をとり精秤し， $105^{\circ} \mathrm{C} て ゙ 5$ 時間加熱した後 デシケーター中で 30 分間放冷し，再度精秤した。水分 減少量から $100 \mathrm{~g}$ あたりのチーズの水分量を計算した.

\section{3 色調測定}

保存後のカマンベール打よびゴーダチーズの色調を カラーアナライザー色差計（TES-135A プラス，佐藤 商事製）を用いて測定した。色調は付属の校正シート を用いて白色校正を行い，色差計の絶対測定モードに より L*a*b*表色系で測定した。両チーズとも表面打よ び内部の断面を各 5 点ずつ計測した。ゴーダチーズの 断面の測定には厚さ $2 \mathrm{~cm}$ でカットしたものの断面につ いて測定し，カマンベールチーズでは半分に縦断した ものの断面を測定した.

\section{4 ガスクロマトグラフィー質量分析機（GC-MS） による香気成分の分析}

それぞれのチーズに含まれる香気成分に関して，ダ イナミックヘッドスペース法による香気成分の捕集と， GC-MS（QP5050A，島津製作所）を用いた分析により 測定した。すなわち，細かく刻んだ各チーズ $1 \mathrm{~g}$ と内部 標準液（ $0.1 \%$ 1-ブタノール） $50 \mu \mathrm{L}$ を入れた丸底フラ スコを $60^{\circ} \mathrm{C}$ の恒温槽に入れて固定し，流量 $50 \mathrm{~mL} /$ 分の 窒素ガスでパージしながら 10 分間加温することにより, 揮発した香気成分を捕集管内に設置した MonoTrap （RGC18TD，ジーエルサイエンス製）に吸着させた. 香気成分を吸着させた捕集管と MonoTrap を加熱脱着

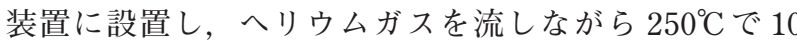
分加熱することにより吸着した香気成分を熱脱離させ た。分離カラムは DB-WAX（アジレント製， $0.25 \mathrm{~mm}$ 
$\times 30 \mathrm{~m}$, 膜厚 $0.25 \mu \mathrm{m})$ を用い,ヘリウム $(120 \mathrm{kPa}$ 定圧 $)$ をキャリアガスとして $37^{\circ} \mathrm{C}(5$ 分 $) \rightarrow 200^{\circ} \mathrm{C}$ まで昇温 $5^{\circ} \mathrm{C} /$ 分 $\rightarrow 250^{\circ} \mathrm{C}$ まで昇温 $20^{\circ} \mathrm{C} /$ 分 $\rightarrow 250^{\circ} \mathrm{C}$ (5 分) のカラ ムオーブン温度で成分を分離した. MS では，イオン化 法 : $\mathrm{EI}$ 法，インターフェース温度 : $230^{\circ} \mathrm{C}$ ，イオン源温 度 : $250^{\circ} \mathrm{C}$, 分析モード：スキャンモード $(\mathrm{m} / \mathrm{z}$ 29-350）により測定した。 ピークの高さから香気成分 量を定量するとともに，匂いかぎによりそれぞれのピー クの匂いについて評価した。それぞれの香気成分は CLASS-5000 software を用いたシミラリティ検索によ り同定した。

\section{5 テクスチャーの評価}

ゴーダチーズとカマンベールチーズのテクスチャー （硬さ, 粘着力, 凝集性, 弾力性, 咀嚼性) について, テクスチュロメーター（JSV-TEX-100，日本計測シス テム製)を用いて評価した。高さ $2 \mathrm{~cm}$ のそれぞれのチー ズについて, 直径 $20 \mathrm{~mm}$ の円柱プランジャーを用い, 試験速度 $0.5 \mathrm{~mm} /$ 秒，圧縮移動距離 $5 \mathrm{~mm}$ の条件で測 定した。負荷を与えた際の最大荷重を硬さ，圧縮後プ ランジャーを引き上げた際の負の荷重を粘着力，1 ス卜 ロークと 2 ストロークの圧縮エネルギーの比を凝集性, 最大ピークに至る変化量の 1 ストロークと 2 ストロー クの比を弾力性として表した。咀嚼性は硬さ×凝集性 ×弾力性で求めた。

\section{6 官能評価}

新潟県立大学の女子学生 40 人（19～22 歳の健康的な 女性）を対象とし，プラスチックのコップに冷蔵庫保
存および雪室モデル保存のチーズを入れ，被験者に配 布した。 2 種類のチーズを 2 点嗜好法打よび 5 点評価法 により評価した． 2 点嗜好法では，2つのチーズのうち 好ましいと思う方を選択し，得られた結果について二 項検定により検定した。評価法では，カマンベールチー ズとゴーダチーズでは色，香り，味，歯ごたえ，舌触り， 酸味，塩味，苦味，総合評価の 9 項目，ブルーチーズ では色，すっぱいに扔，かびくささ，刺激臭（ツン とするにおい), アンモニア臭, 腐敗臭, 生ごみのにおい, 総合評価 (香り) の 8 項目について $-2 \sim 2$ 点で評価した. 検定は，それぞれの項目の平均值について，t検定を用 いて行った。

\section{7 統計処理}

データは平均值士標準偏差として表示した。統計処 理は $\mathrm{R}$ プログラム（v3.1.3）を用い，2 群は $\mathrm{t}$ 検定，3 群は Tukey-Kramer 法による多重比較で行い，いずれ も $5 \%$ を有意水準とした。

\section{3. 結果および考察}

\section{1 雪室モデルの温度・湿度変化}

実験期間中における冷蔵庫と雪室モデルの温度およ び湿度の変化を Fig. 1 に示す. 冷蔵庫は $2 \sim 7^{\circ} \mathrm{C}$ の間で 大きく温度が変化していたのに対し（最高 $7.3^{\circ} \mathrm{C}$ ，最低 $1.9^{\circ} \mathrm{C}$; 平均 $3.5^{\circ} \mathrm{C}$ ), 雪室モデルは $1 \sim 2^{\circ} \mathrm{C}$ の安定した低 温を示した (最高 $1.7^{\circ} \mathrm{C}$, 最低 $0.8^{\circ} \mathrm{C}$; 平均 $\left.1.2^{\circ} \mathrm{C}\right)$. 湿 度についても同様に，冷蔵庫は 10～35\%の低湿度状態 にあったのに対し（最高 $34.9 \%$, 最低 $8.0 \%$; 平均 $9.5 \%$ ),
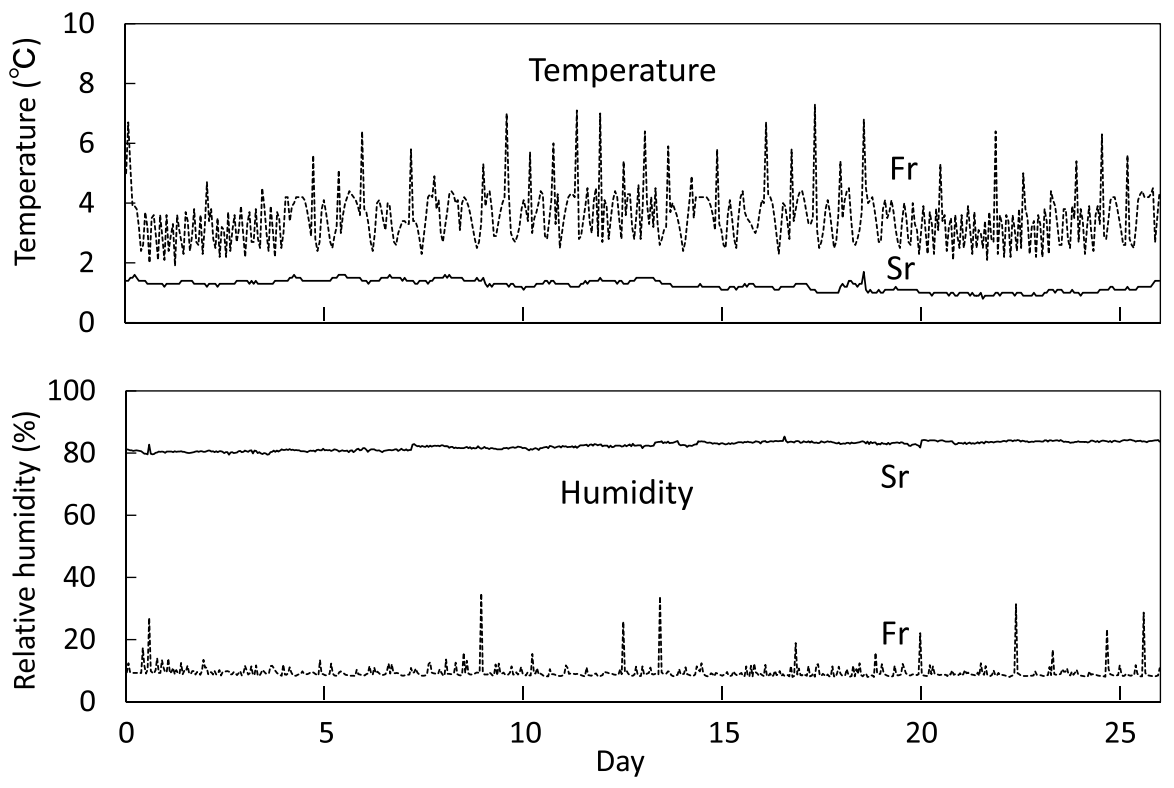

Fig.1 Alterations of temperature and humidity in the refrigerator and snow-storage room model used in this study. The temperature and humidity in the refrigerator and snow storage room was monitored using hygrothermo recorders. 
雪室モデルは 80～85\%の安定した高湿度を保っていた (最高 $85.3 \%$ ，最低 $79.5 \%$ ；平均 $82.0 \%$ )。これらの結 果から，雪室モデルが実際の水雪型雪室（温度 $0 \sim 5{ }^{\circ} \mathrm{C}$, 湿度 $90 \%$ 以上） と類似した保存条件であることが確認 された。

\section{2 試料の水分量}

まず，温度・湿度に変動のある冷蔵モデルと雪室モ デルに拍けるチズの保存による水分変化の状態をみ るために，水分量の多い軟質チーズであるカマンベー ルチーズを 8 等分 $(15 \mathrm{~g}$ 程度) にカットしたものを, 上述の冷蔵庫と雪室モデルに開封状態（プラスチック カップに入れろ紙で蓋をしたもの） あるいは水分を通 さないガスバリア性のラミネート包装で簡易密封した 状態で 1 ケ月間保存し，それぞれの水分変化を比較検 討した．Fig. 2 に示したように，封をせずにカップ内に 保存した状態では，低湿度の状態にある冷蔵庫では初 発状態の $1 / 3$ 以下に水分量が減少したのに対し，湿度 $80 \%$ 以上である雪室モデルではほとんど変化がみられ なかった。一方，水分を通さないラミネート包装で簡 易密封した場合でも，温度・湿度に変動のある冷蔵庫 に保存したものは $10 \%$ 程度水分が減少していたのに対 し，雪室モデル貯蔵のものはほとんど水分変化がみら れなかった。ここで，今回用いた包装は真空包装では なく，包装と試料との間に間隙がある状態であったた め，冷蔵庫に打ける温度の上下にともない蒸発・凝縮 を繰り返すことにより結露し，水分量の減少をもたら したものと考えられる。したがって，冷蔵庫において も雪室モデルと同様の温度変化のない低温を維持でき る状態であれば，初期状態と同じ水分量を維持できる ものと考えられる。

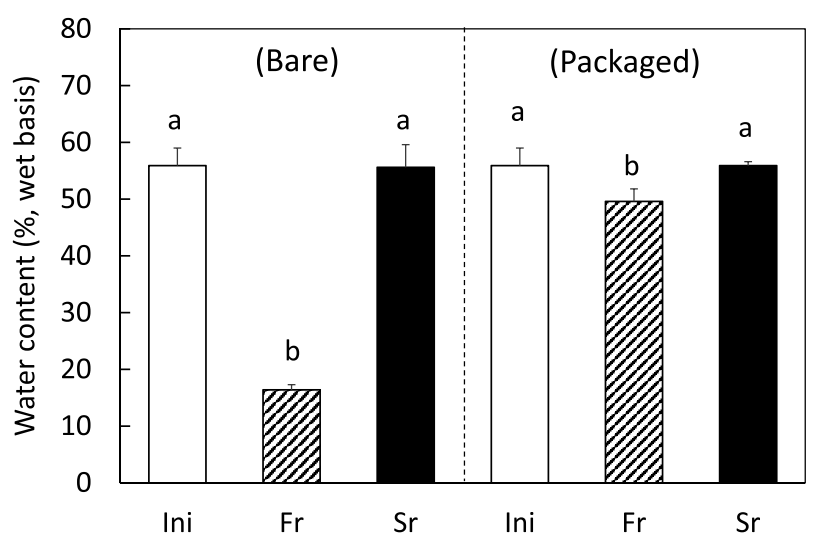

Fig. 2 Water content (\%, wet basis) of cheeses stored in the refrigerator and snow-storage room model. Bare, stored under air-exposed conditions; Packaged, sealed in a gas barrier package. Ini, initial state; Fr, refrigerator; Sr, snowstorage room. $\mathrm{n}=3$.

${ }^{\mathrm{a}, \mathrm{b}}$ Different letters above bars indicate significant differences $(P<0.05)$
さらに，カットしない状態のカマンベールチーズ (ホール，100 g) と，半硬質チーズであるゴーダチー ズ（カット，100 g) について，同様にラミネート包装 で密封し，温度・湿度に変化のある冷蔵庫あるいは雪 室モデルに1ヶ月間保存した.カマンベールチーズでは, 雪室モデルに保存したものの水分量は $56.6 \pm 2.4 \%$ と初 発水分量 $(55.9 \pm 3.1 \%)$ とほとんど変化がみられなかっ たが，冷蔵庫に保存したものは $41.0 \pm 3.9 \%$ と有意に減 少していた $(n=4$, 初発と冷蔵庫, 雪室モデルと冷蔵庫 との間で $P<0.05)$ ，一方，半硬質チーズであるゴーダ チーズの水分量（初発水分量 $40.0 \pm 1.2 \%$ ） は，雪室乇 デルで $39.5 \pm 0.6 \%$, 冷蔵庫で $38.7 \pm 2.3 \%(n=4)$ であり, いずれも有意差はみられなかった。なお，本項目の水 分量は常圧乾燥法 $\left(105^{\circ} \mathrm{C}\right)$ で求めて打り，水分以外の 揮発性成分が含まれることについては考慮していない。

\section{3 色調}

チーズは乾燥状態や熟成の状態により，水分減少や 成分変化，微生物の発生が生じて色調の変化がみられ る. 3.2 で用いた簡易密封状態のカマンベールチーズ (ホール $100 \mathrm{~g}$ ) とゴーダチーズ（カット $100 \mathrm{~g}$ ）につい て，初発状態打よび冷蔵庫保存と雪室モデル保存のも のの色調の違いをカラーアナライザーを用いて測定し た。色調は $\mathrm{L}^{*} \mathrm{a} * \mathrm{~b}^{*}$ 表色系として表すとともに，それそ れの色差 $\left(\Delta \mathrm{E}^{*}{ }_{\mathrm{ab}}\right)$ を求めて評価した. Table 1 に示し たように，ゴーダチーズ，カマンベールチーズともに 雪室モデル保存のものは初発状態のものと色差が少な かったが，温度・湿度に変動のある冷蔵庫に保存した ものは色調に大きな変化がみられた。雪室モデル保存 と冷蔵庫保存との間の比較では，ゴーダチーズでは表 面の色差はわずかであったが，断面の色は著しく異なっ て扔り，一方，カマンベールチーズについては，断面 の色差は少なかったが，表面の色はきわめて著しく異 なっていた。とくにカマンベールチーズでは上部が水 分の減少により硬くなっており，硬い部分の色は黄色 みがかっていた。雪室モデル保存は水分量の減少と過 熟成を防ぐことにより，チーズの色調変化を抑制する ことが示唆された。

\section{4 テクスチャー}

上述の簡易密封状態で冷蔵庫あるいは雪室モデルに 保存したそれぞれのチーズの食感について，テクス チャー試験機を用いた 2 回繰り返し圧縮によるテクス チャープロファイル法により評価した. Table 2 に示す ように，硬さと咀嚼性，ガム性に関しては，カマンベー ルチーズとゴーダチーズのいずれに打いても，雪室モ デル保存と初発状態との間で有意差がみられなかった が，冷蔵庫に保存したものは両方に対し有意に高い值 を示した。とくにカマンベールチーズに打いては，冷 
Table $1 \mathrm{~L}^{*} \mathrm{a}^{*} \mathrm{~b}^{*}$ color and total color difference of cheeses stored in the refrigerator and snow storage-room model.

\begin{tabular}{|c|c|c|c|c|c|c|}
\hline & & $\mathrm{L}^{*}$ & $a^{*}$ & $b^{*}$ & $\Delta \mathrm{E}_{\mathrm{ab}}^{*}$ & NBS Unit $^{1}$ \\
\hline \multirow{3}{*}{$\begin{array}{l}\text { Camembert } \\
\text { (surface) }\end{array}$} & Ini & $97.13 \pm 1.20^{\mathrm{a}}$ & $-0.12 \pm 0.19^{a}$ & $4.01 \pm 0.33$ & Ini-Fr 8.63 & Ini-Fr 7.93 \\
\hline & $\mathrm{Fr}$ & $88.58 \pm 2.10^{b}$ & $0.77 \pm 0.29^{b}$ & $4.77 \pm 1.19$ & Ini-Sr 1.98 & Ini-Sr 1.82 \\
\hline & $\mathrm{Sr}$ & $98.76 \pm 0.20^{\mathrm{a}}$ & $-0.33 \pm 0.32^{\mathrm{a}}$ & $5.12 \pm 0.42$ & Fr-Sr 10.24 & Fr-Sr 9.42 \\
\hline \multirow{3}{*}{$\begin{array}{l}\text { Camembert } \\
\text { (inner) }\end{array}$} & Ini & $96.21 \pm 2.36^{\mathrm{a}}$ & $0.13 \pm 0.49$ & $15.55 \pm 0.60^{\mathrm{a}}$ & Ini-Fr 5.14 & Ini-Fr 4.73 \\
\hline & $\mathrm{Fr}$ & $91.38 \pm 1.35^{\mathrm{b}}$ & $-1.07 \pm 1.42$ & $16.85 \pm 0.66^{\mathrm{b}}$ & Ini-Sr 2.08 & Ini-Sr 1.91 \\
\hline & $\mathrm{Sr}$ & $95.07 \pm 1.41^{\mathrm{a}}$ & $-0.07 \pm 0.73$ & $13.82 \pm 0.24^{\mathrm{c}}$ & Fr-Sr 4.88 & Fr-Sr 4.49 \\
\hline \multirow{3}{*}{$\begin{array}{c}\text { Gouda } \\
\text { (surface) }\end{array}$} & Ini & $82.90 \pm 0.61$ & $0.97 \pm 0.29$ & $24.82 \pm 0.49$ & Ini-Fr 1.44 & Ini-Fr 1.33 \\
\hline & $\mathrm{Fr}$ & $81.46 \pm 2.63$ & $0.99 \pm 0.67$ & $24.88 \pm 1.57$ & Ini-Sr 0.14 & Ini-Sr 0.13 \\
\hline & $\mathrm{Sr}$ & $82.99 \pm 0.99$ & $1.08 \pm 0.58$ & $24.85 \pm 0.77$ & Fr-Sr 1.53 & Fr-Sr 1.40 \\
\hline \multirow{3}{*}{ Gouda (inner) } & Ini & $83.66 \pm 1.60^{\mathrm{a}}$ & $0.17 \pm 0.22^{\mathrm{a}}$ & $24.76 \pm 0.90$ & Ini-Fr 2.94 & Ini-Fr 2.71 \\
\hline & $\mathrm{Fr}$ & $81.33 \pm 1.07^{\mathrm{b}}$ & $1.88 \pm 1.25^{\mathrm{b}}$ & $25.28 \pm 0.89$ & Ini-Sr 1.23 & Ini-Sr 1.13 \\
\hline & $\mathrm{Sr}$ & $84.84 \pm 0.50^{\mathrm{a}}$ & $0.42 \pm 0.61^{\mathrm{a}}$ & $24.97 \pm 0.57$ & Fr-Sr 3.82 & Fr-Sr 3.51 \\
\hline
\end{tabular}

Ini, initial state; Fr, refrigerator; Sr, snow-storage room model. $n=5$.

${ }^{1} \mathrm{NBS}$ (National Bureau of Standards) Unit $=\Delta \mathrm{E}^{*}{ }_{\mathrm{ab}} \times 0.92$

Critical remarks of NBS units are as follows: 0-0.5, trace; 0.5-1.5, slight; $1.5-3.0$, noticeable; $3.0-6.0$, appreciable; $6.0-$ 12.0 , much; $12.0<$, very much.

Table 2 Texture of Camembert and Gouda cheeses stored in the refrigerator and snow-storage room model.

\begin{tabular}{|c|c|c|c|c|c|c|c|}
\hline & & $\begin{array}{l}\text { Hardness } \\
\left(\mathrm{kN} / \mathrm{m}^{2}\right)\end{array}$ & $\begin{array}{l}\text { Adhesiveness } \\
\left(\mathrm{kN} / \mathrm{m}^{2}\right)\end{array}$ & $\begin{array}{c}\text { Cohesiveness } \\
\text { (Ratio) }\end{array}$ & $\begin{array}{l}\text { Springiness } \\
\text { (Ratio) }\end{array}$ & $\begin{array}{c}\text { Gumminess * } \\
\left(\mathrm{kN} / \mathrm{m}^{2}\right)\end{array}$ & $\begin{array}{c}\text { Chewiness } \\
\left(\mathrm{kN} / \mathrm{m}^{2}\right)\end{array}$ \\
\hline \multirow{3}{*}{$\begin{array}{c}\text { Camembert } \\
\text { (vertical) }\end{array}$} & Ini & $3.86 \pm 1.40^{\mathrm{a}}$ & $0.11 \pm 0.12$ & $0.56 \pm 0.08^{\mathrm{a}}$ & $0.64 \pm 0.06^{\mathrm{a}}$ & $2.22 \pm 0.80^{\mathrm{a}}$ & $1.47 \pm 1.03^{\mathrm{a}}$ \\
\hline & Fr & $12.75 \pm 3.51^{\mathrm{b}}$ & $0.02 \pm 0.02$ & $0.52 \pm 0.06^{\mathrm{a}}$ & $0.58 \pm 0.08^{\mathrm{a}}$ & $6.77 \pm 2.21^{\mathrm{b}}$ & $4.05 \pm 1.55^{\mathrm{b}}$ \\
\hline & $\mathrm{Sr}$ & $3.42 \pm 1.50^{\mathrm{a}}$ & $0.10 \pm 0.17$ & $0.44 \pm 0.06^{\mathrm{b}}$ & $0.52 \pm 0.04^{b}$ & $1.46 \pm 0.50^{\mathrm{a}}$ & $0.76 \pm 0.25^{\mathrm{a}}$ \\
\hline \multirow{3}{*}{$\begin{array}{l}\text { Camembert } \\
\text { (horizontal) }\end{array}$} & Ini & $2.64 \pm 1.20^{\mathrm{a}}$ & $0.62 \pm 0.11$ & $0.61 \pm 0.14$ & $0.88 \pm 0.18$ & $1.65 \pm 0.91^{\mathrm{a}}$ & $1.47 \pm 0.85^{\mathrm{a}}$ \\
\hline & Fr & $9.59 \pm 4.58^{\mathrm{b}}$ & $0.52 \pm 0.13$ & $0.52 \pm 0.10$ & $0.76 \pm 0.12$ & $5.09 \pm 3.01^{\mathrm{b}}$ & $3.98 \pm 2.54^{b}$ \\
\hline & $\mathrm{Sr}$ & $1.88 \pm 0.64^{\mathrm{a}}$ & $0.78 \pm 0.47$ & $0.63 \pm 0.10$ & $1.13 \pm 0.73$ & $1.14 \pm 0.28^{\mathrm{a}}$ & $1.32 \pm 0.98^{\mathrm{a}}$ \\
\hline \multirow{3}{*}{ Gouda } & Ini & $50.67 \pm 11.49^{\mathrm{a}}$ & $0.25 \pm 0.16$ & $0.70 \pm 0.04^{\mathrm{a}}$ & $0.84 \pm 0.08$ & $35.15 \pm 6.63^{\mathrm{a}}$ & $29.55 \pm 6.18^{\mathrm{a}}$ \\
\hline & $\mathrm{Fr}$ & $79.25 \pm 16.93^{b}$ & $0.14 \pm 0.10$ & $0.77 \pm 0.02^{b}$ & $0.86 \pm 0.03$ & $60.68 \pm 12.45^{b}$ & $52.42 \pm 12.11^{\mathrm{b}}$ \\
\hline & $\mathrm{Sr}$ & $49.14 \pm 5.74^{\mathrm{a}}$ & $0.14 \pm 0.07$ & $0.77 \pm 0.01^{\mathrm{b}}$ & $0.83 \pm 0.03$ & $37.92 \pm 4.64^{\mathrm{a}}$ & $31.53 \pm 4.54^{\mathrm{a}}$ \\
\hline
\end{tabular}

Ini, initial state; Fr, refrigerator; Sr, snow-storage room model.

${ }^{\mathrm{a}, \mathrm{b}}$ Different letters within a column indicate significant difference $(P<0.05) . n=6$.

${ }^{*}$ hardness $\times$ cohesiveness ${ }^{* *}$ hardness $\times$ cohesiveness $\times$ springiness

蔵庫保存のチーズに打ける横方向（断面内部）の硬さ の值は雪室モデル保存のものの 5 倍程度の值を示した. 冷蔵庫に保存したものは水分の減少がみられたことか ら，それに伴い内部の硬さが増加したものと考えられ る。一方，縦方向の凝集性と弾性の值は雪室モデルで 初発状態抢よび冷蔵庫保存のものよりも有意に低下し ており，雪室モデルに保存したものはより軟らかい状 態になっていることが示唆された。 以上のことから, 雪室モデルで保存したチーズはやわらかさが維持され ており, 温度・湿度に変動のある冷蔵庫に保存したも のよりも咀嚼に必要なエネルギーも低く良好なテクス チャーであることが示された.

\section{5 香気分析}

以前の研究で，玄そば [7] やコーヒー [3] の貯蔵にお
いては，雪室貯蔵により冷蔵庫貯蔵と比べて香気の保 持あるいは改善効果がみられることを示した。チーズ においても同様に，雪室モデルによる貯蔵で香気保持 効果がみられるかどうかを検討するため，代表的な匂 いの強いチーズであるブルーチーズ（キャステロブ ルー）を内部から外部へのガス抜きバルブ付きラミネー 卜包装材で簡易密封した状態で，温度・湿度に変動の ある冷蔵庫あるいは雪室モデルに 1 ヶ月保存し，匂い かぎ付き GC-MSで香気成分を分析することにより， 保存環境がブルーチーズの特徴的な香気成分に及ぼす 影響を検討した. Fig. 3 と Table 3 に保存開始時と終了 時のそれぞれのクロマトグラムと香気成分の定量結果 を示す。雪室モデルに保存したブルーチーズでは，冷 蔵庫保存ではみられなかったピークが検出されるとと もに，2-ヘプタノン，2-ヘプタノール，2-ノナノン， 

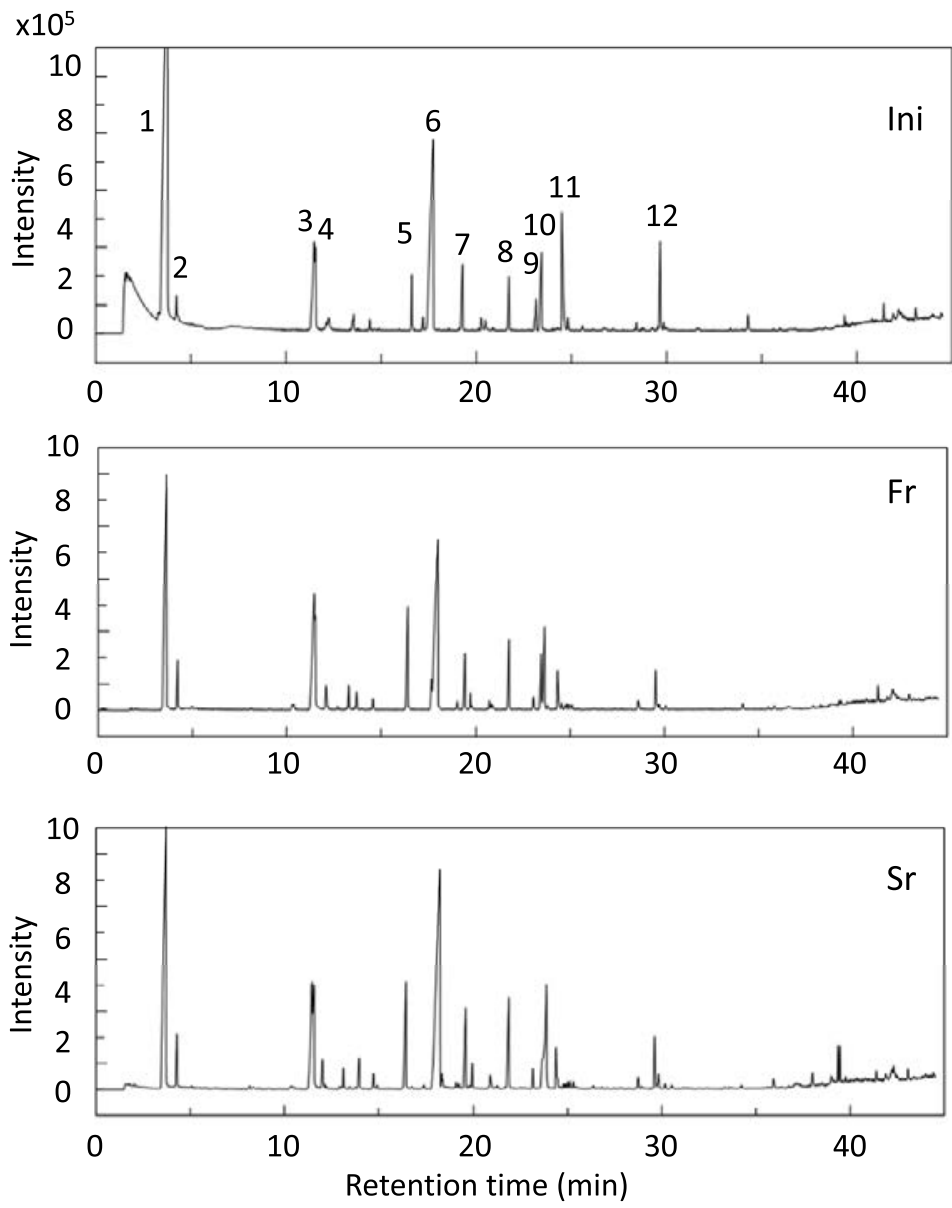

Fig. 3 GC-MS chromatograms of Danish blue cheeses stored in the refrigerator and snow-storage room model. Ini, initial state; Fr, refrigerator; Sr, snow-storage room model. Peak 1, methanol (etc., impure); 2, ethanol; 3, internal standard; 4, 2-heptanone; 5, 2- heptanol; 6, 2- nonanone; 7, 8-nonen-2-one; 8, 2-nonanol; 9, methyl decanoate; 10, 2-undecanone; 11, butyric acid; 12 , hexanoic acid.

Table 3 The amounts of odor components detected in Danish blue cheeses stored in the refrigerator and snow-storage room model.

\begin{tabular}{cccccc}
\hline & Ethanol & 2-heptanone & 2-heptanol & 2-nonanone & $\begin{array}{c}\text { 8-nonen-2- } \\
\text { one }\end{array}$ \\
\hline Ini & $0.16 \pm 0.10$ & $0.31 \pm 0.10^{\mathrm{a}}$ & $0.21 \pm 0.04^{\mathrm{a}}$ & $3.29 \pm 0.20^{\mathrm{a}}$ & $0.45 \pm 0.03^{\mathrm{a}}$ \\
$\mathrm{Fr}$ & $0.20 \pm 0.02$ & $0.20 \pm 0.04^{\mathrm{a}}$ & $0.39 \pm 0.05^{\mathrm{b}}$ & $1.63 \pm 0.14^{\mathrm{b}}$ & $0.21 \pm 0.01^{\mathrm{b}}$ \\
$\mathrm{Sr}$ & $0.37 \pm 0.35$ & $0.66 \pm 0.07^{\mathrm{b}}$ & $0.69 \pm 0.02^{\mathrm{c}}$ & $3.18 \pm 0.47^{\mathrm{a}}$ & $0.42 \pm 0.06^{\mathrm{a}}$ \\
\hline \multicolumn{7}{c}{} \\
\hline \\
\hline \multirow{7}{*}{ Ini } & $0.30 \pm 0.03^{\mathrm{a}}$ & $0.17 \pm 0.02$ & $0.67 \pm 0.07$ & $0.52 \pm 0.36$ & $0.32 \pm 0.22$ \\
$\mathrm{Fr}$ & $0.24 \pm 0.02^{\mathrm{a}}$ & $0.25 \pm 0.04$ & $0.36 \pm 0.01$ & $0.64 \pm 0.43$ & $0.33 \pm 0.19$ \\
$\mathrm{Sr}$ & $0.52 \pm 0.06^{\mathrm{b}}$ & $0.36 \pm 0.17$ & $0.70 \pm 0.33$ & $0.27 \pm 0.17$ & $0.13 \pm 0.10$ \\
\hline
\end{tabular}

The amounts of odor components are showed as the ratio to the intensity of an internal standard. Ini, initial state; Fr, refrigerator; Sr, snow-storage room model. $n=3 .{ }^{\mathrm{a}, \mathrm{b}}$ Different letters within a column indicate significant differences $(P<0.05)$. 
8-ノネン-2-オン，2-ノナノールのようなブルーチー ズに特徵的な香気成分が有意に多く検出された（Table 3).ノイズで正確に分析できなかった分析開始後 4 分 までの部分を除く香気成分の総量（全ピーク面積の合 計量) は, 初発状態が $10.1 \pm 0.5$, 雪室モデルが $11.9 \pm 2.4$, 冷蔵庫が $7.2 \pm 0.8$ であり（内部標準比，雪室モデルと 冷蔵庫との間のみ $P<0.05)$, 雪室モデルで香気成分が 残存していることが確認された。保存条件の差による 品質の違いに加え，この実験で用いた包装はガス抜き バルブが付けてあり，外部の気体は通さないものの内 部からは外部に抜けることができるため，高湿度で温 度変化のない雪室モデルは本実験で用いた低湿度で温 度変化の大きい冷蔵庫よりも香気の保持効果において 優れていたものと考えられる。また，初発状態に比べ て雪室モデルに保存したものでブルーチーズの特徴的 な香気である 2-ヘプタノン，2-ヘプタノール，2-ノナ ノールが有意に増加していたことは，雪室モデルの低 温状態でも 1 ヶ月の保存で発酵が進んだことによるも のと考えられる。

\section{6 官能検査による評価}

これらの試験で用いたチーズの風味について，カマ ンベールチーズとゴーダチーズは食感と味を，ブルー
チーズは匂いを中心に，嗜好法と評価法を用いた官能 検査により評価した.

カマンベールチーズの食味に関する 2 点嗜好法によ る官能評価では，パネル 40 名のうち好ましいとされた 判定数の合計は冷蔵庫保存が 13 , 雪室モデル保存が 27 であり，冷蔵庫保存より雪室モデル保存のチーズが有 意に好まれていた $(P<0.05)$ 。一方，ゴーダチーズの判 定数の合計は冷蔵庫保存が 18 ，雪室モデル保存が 22 であり，有意差はみられなかった。 カマンベールチー ズとゴーダチーズの評価法による官能試験の結果を Fig. 4 (上) に示す. カマンベールチーズでは, 色と味, 舌触りに打いて冷蔵庫に保存したものよりも雪室モデ ル保存のチーズの方が有意に好まれており，また有意 差はみられなかったものの，総合評価でも好まれる傾 向がみられた。したがって，とくにカマンベールチー ズのような水分の多いチーズに扎いては，温度・湿度 に変動のある冷蔵庫に保存したものに比べ，雪室モデ ルに保存したチーズで水分減少と過熟成が抑えられる ことによりやわらかく良好なチーズになることが確認 された。一方，ブルーチーズの匂いについても官能試 験を行ったが，2 点嗜好法による評価は判定数の合計は 冷蔵庫保存で 21 ，雪室モデル保存で 18 であり，有意 差は認められなかった.ブルーチーズの匂いについて

\section{Camembert (tasting)}

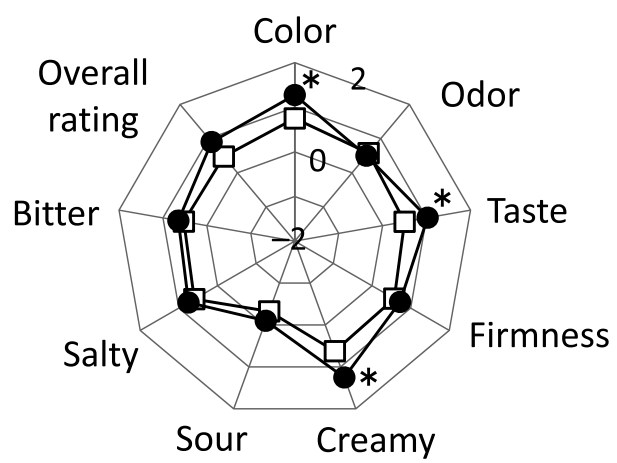

Gouda (tasting)

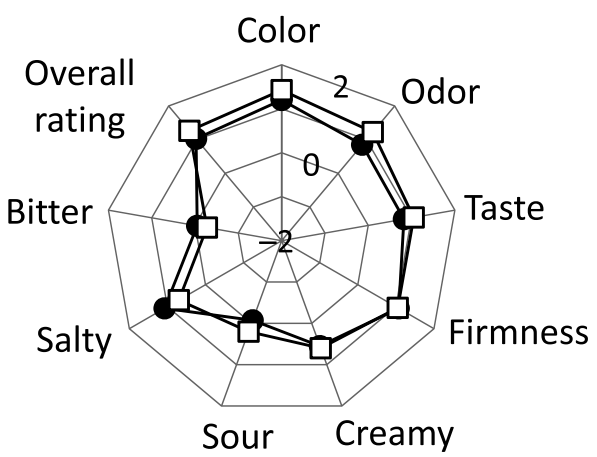

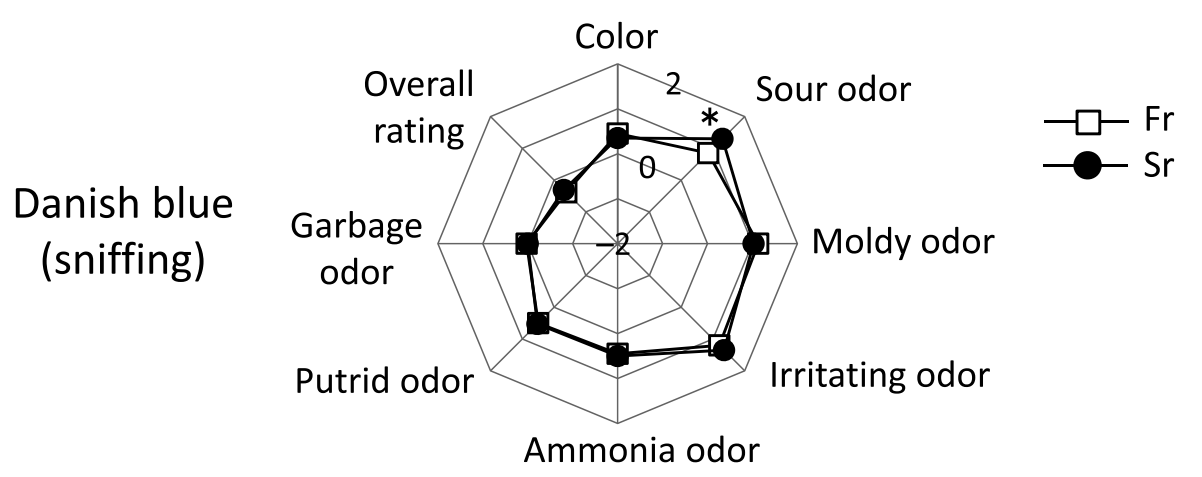

Fig. 4 Sensory evaluation of cheeses stored in the refrigerator and snow-storage room model. Upper left, Camembert cheese; upper right, Gouda cheese; lower, Danish blue cheese. Each attribute was expressed on a five-point scale from -2 (bad) to +2 (good). Fr, refrigerator; Sr, snowstorage room model. Asterisks indicate significant differences $(P<0.05)$. 
の評価法による官能試験の結果を Fig. 4(下)に示す. ブルーチーズでは，「すっぱいに扔い」に打いて冷蔵庫 保存より雪室モデル保存のチーズの方が有意に強く感 じると評価されたが，それ以外の項目では有意差は認 められなかった，鼻先香による匂いの違いの評価では， 1ヶ月の保存では大きな差が生じなかったと考えられ， より長期の貯蔵試験が必要であるものと考えられる.

4. 結

論

雪室モデルを用いた検討により，水分の多いカマン ベールチーズでは温度・湿度に変動のある冷蔵状態に 比べ，安定した低温・高湿度を維持できる雪室保存で 水分の減少と色の変化が抑えられることが示された. その結果，雪室モデルに保存したチーズはやわらかい 状態が維持され，また，食感だけでなく，味も含め官 能的にも雪室モデルに保存したチーズが有意に好まれ ることが明らかにされた。 また，香気に関しても，ガ ス抜きバルブ付き包材に保存したブルーチーズでは, 温度・湿度に変動のある冷蔵庫で保存したものよりも 雪室モデル保存のものでブルーチーズに特徴的な香気 が多く保持されていることが示された。

本研究により，チーズの保存に打いても，温度変化 が少なく高湿度である雪室保存が有効であることが示 された。雪室は一般的なチーズの熟成庫よりは低温で あるものの，チーズの熟成に好適な空気振動のない高 湿度条件であることから，今後，チーズのような乳製 品に対しても，雪室を利用した熟成が活用されること が期待される。

\section{謝辞}

GC-MS による分析にあたっては，新潟県農業総合研 究所食品研究センターの小林和也先生と渡辺聡先生に ご協力いただきました。哚く感謝申し上げます。

\section{References}

1) K. Ishihara, H. Suzuki, S. Tsuchida, K. Umano, Y. Hagi, Y. Yokoyama; "Change in volatile compounds in carrot stored under snowy ground" (in Japanese). Hort. Res. (Japan), 4, 353-357 (2005).

2) K. Muramatsu; "Snow storage of vegetables" (in Japanese). Bull. Hokuriku Natl. Agric. Exp. Stn., 29, 75-94 (1987).

3) H. Sone, M. Oshimi, M. Ito, M. Ishiguro, T. Tsuji, K.
Kobayashi, S. Watanabe, S. Kamiyama; "Effect of snow room storage on changes in aromatic compounds of roasted coffee beans" (in Japanese). Trace Nutrients Res., 31, 12 16 (2014)

4) S. Kamiyama, S. Kushihara, C. Homma, M. Hagiwara, H. Sone; "Effectiveness of snow utilization for preservation of wheat flour" (in Japanese). Jpn. J. Food Engineer., 18, 19-24 (2017).

5) S. Kamiyama, A. Usui, H. Sone; The effect of snow utilization on the fravor of Japanese sake: examination by a model experiment and sensory evaluation. (in Japanese). Bull. Soc. Life Cult. Niigata, 24, 11-14 (2018).

6) K. Sagara; "Ripening of cheese at low temperature and that quality” (in Japanese). Food Preserv. Sci., 22, 251-257 (1996).

7) S. Kamiyama, M. Itoh, M. Oshimi, M. Takiguchi, S. Kushihara, M. Ishiguro, K. Kobayashi, S. Shimojo, S. Watanabe, H. Sone; "The efficacy of snow room (yukimuro) storage for the preservation of buckwheat grain" (in Japanese). Bull. Soc. Hum. Life Stud., 6, 83-92 (2015).

\section{引用 $\mathbf{U} \mathbf{R} \mathbf{L}$}

i) National Land Council of Ministry of Land, Infrastructure, Transport and Tourism of Japan. www.mlit.go.jp/common/001220015.pdf (Mar. 26, 2018)

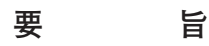

本研究は，人工的に雪室環境を再現した雪室モデル を用いることにより，チーズの保存における雪利用の 有効性について検討した．水分の多いカマンベールチー ズを温度・湿度に変動のある冷蔵庫あるいは雪室モデ ルに 1 ケ月間保存した場合，簡易密封した状態でも冷 蔵庫保存よりも雪室モデル保存で水分の減少と色の変 化が抑えられることが示された。雪室モデルに保存し たチーズはテクスチャーも良好であり，官能評価にお いても有意に好まれることが示された。また，香気に 関しても，ガス抜きバルブ付きの包材に保存したブルー チーズでは，温度・湿度に変動のある冷蔵状態で保存 したものよりも雪室モデル保存のもので特徵的な香気 が多く保持されていることが示された。これらの結果 から，温度変化が少なく高湿度である雪室はチーズの 保存と熟成に拈いても有効であることが示された。 